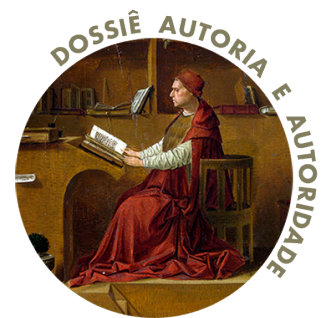

ENTRE ANTIGOS E MODERNOS
ARTIGO

integra o Dossiê Autoria e Autoridade: entre Antigos e Modernos

Contato

Estrada do Caminho Velho, Jardim Nova Cidade 07252312 - Guarulhos - São Paulo - Brasil renatacjm@gmail.com

\section{O CONSELHO}

ULTRAMARINO E AS

QUEIXAS E AGRAVOS

DO ULTRAMAR

PORTUGUÊS (MINAS

GERAIS, 1750-1808)'

\section{- Renata Silva Fernandes ${ }^{2}$}

Universidade Federal de São Paulo

Guarulhos - São Paulo - Brasil

\title{
Resumo
}

O objetivo deste artigo é examinar alguns dos tipos de queixa a partir das quais os súditos do ultramar buscavam e muitas vezes logravam a intercessão do monarca e de seu Conselho Ultramarino frente às condutas antijurídicas dos oficiais. Explicar esses mecanismos requer identificar suas conformações, considerando a "condição" de quem pedia, a forma a partir da qual se pedia, as razões pelas quais se pedia, os "remédios" efetivamente pedidos e, não menos importante, os procedimentos institucionais que suscitaram no Conselho Ultramarino - aspectos que podem, como argumentarei, ser, em boa medida, lastreados na sedimentação documental e arquivística da instituição. Para tanto, parto do corpus documental da instituição pertinente à capitania de Minas Gerais na segunda metade do século XVIII. Meu enfoque será o mundo formal e institucional tomando-o como dimensão relevante para compreensão da cultura jurídica do período e dos dispositivos a partir dos quais o poder régio, através de seu Conselho Ultramarino, se fazia presente nos territórios do ultramar e exercia, direta ou indiretamente, uma função de controle, ou ao menos, de tutela e disciplina sobre o oficialato.

\section{Palavras-chave}

ConselhoUltramarino-Minas Gerais-Garantia dedireitos-Petições extrajudiciais-Queixas

\footnotetext{
1 Artigo não publicado em plataforma preprint. Todas as fontes e bibliografia utilizadas são referenciadas no artigo. $\mathrm{O}$ artigo apresenta os resultados preliminares da pesquisa de pós-doutorado intitulada "As petições extrajudiciais e a garantia de direitos no ultramar, 1750-1808" desenvolvida na Universidade Federal de São Paulo com financiamento da Fundação de Apoio à Pesquisa do Estado de São Paulo - FAPESP (processo no 19/00456-0).

2 Doutora em História pela Universidade Federal de Juiz de Fora. Pesquisadora de Pós-Doutorado (FAPESP) na Universidade Federal de São Paulo.
} 


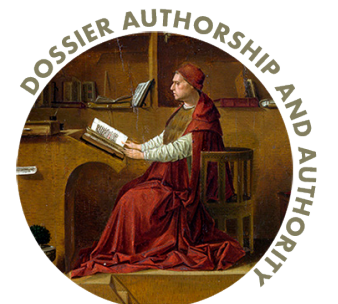

BETWEEN ANCIENTS AND MODERNS
ARTICLE integrates the Dossier Authorship and Authority: between Ancients and Moderns
Contact

Estrada do Caminho Velho, Jardim Nova Cidade 07252312 - Guarulhos - São Paulo - Brazil renatacjm@gmail.com

\section{THE OVERSEAS}

COUNCIL AND THE

COMPLAINTS AND

AGRAVOS OF THE

PORTUGUESE OVERSEAS

(MINAS GERAIS,

1750-1808)

- Renata Silva Fernandes

Universidade Federal de São Paulo

Guarulhos - São Paulo - Brazil

\begin{abstract}
This article intends to examine some of the types of complaints from which overseas subjects sought and often succeeded in securing the intercession of the monarch and his Overseas Council in the face of officers' anti-legal conduct. Explaining these instruments requires identifying their configurations, considering the "condition" of the person who asked, the way in which they asked, the reasons why they asked, the "remedies" actually requested, and, last, but not least, the institutional procedures that gave rise to at the Overseas Council - aspects that may, as I will argue, be, to a large extent, backed by the institution's documents and archives. To do so, I depart from the corpus of the institution relevant to the capitania of Minas Gerais in the second half of the 18th century. My focus will be the formal and institutional world, considering it as a relevant dimension for understanding the legal culture of the period and the devices from which the royal power, through its Overseas Council, was present in the overseas territories and exercised, directly or indirectly, a function of control, or at least, of tutelage and discipline over the official corps.
\end{abstract}

\title{
Keywords
}

Overseas Council - Minas Gerais - Guarantee of Rights - Extrajudicial Petitions -Complaints 
Nas últimas décadas, no bojo do significativo desenvolvimento dos debates em torno da administração no Império Português - e na América Portuguesa particularmente ${ }^{3}$ - a dinâmica e multifacetada comunicação política entre o centro de poder, os diferentes agentes, corpos e instituições e os vassalos espalhados pelos territórios tem ocupado, em definitivo, um lugar de destaque na agenda dos historiadores.

Dos muitos tópicos de discussão, e pari passu à emergência de perspectivas renovadas sobre o tradicional tema da suposta arbitrariedade, inaptidão e corrupção do oficialato português ${ }^{4}$, vários trabalhos destacaram a centralidade de um modo de comunicação política comum no Império Português e alhures: a prática de "tempos imemoriais" (CARDIM, 1998, p. 134), amplamente difundida e conhecida nos dois lados do atlântico de se apresentar omisso medio ao rei e aos órgãos que agiam em seu nome queixas e agravos diante de, entre outros motivos, violências, abusos, injustiças ou simplesmente da inação do oficialato (RUSSELL-WOOD, 2000, BICALHO, 2017; MONTEIRO \& COSENTINO, 2017; ROMEIRO, 2017). As queixas e agravos ocupavam então um lugar central no seio das práticas sociojurídicas que marcavam aquele ordenamento jurisdicional e pluralista regido por uma lógica "garantista de direitos", posto que subjetivos, hierárquicos e desiguais (Cf. GARRIGA, 2008). Nesse sentido, para o caso da América Portuguesa, assume particular relevo a atuação do Conselho Ultramarino, instituição que se dedicava aos assuntos das conquistas, evidente através do grande conjunto documental preservado pela instituição. ${ }^{5}$

Mas havia, em realidade, diferentes tipos de queixume, assim como eram vários os caminhos que estes poderiam seguir dentro do próprio Conselho Ultramarino, a depender da condição e status do autor (particular ou corpo político, individual ou coletivo, etc.), das práticas ou comportamentos arguidos e natureza dos "direitos" ofendidos e dos objetivos específicos dos atos comunicacionais. Algumas das formas de expressão de queixume ou reclame quanto às condutas dos oficiais, é bem verdade, foram objeto de análises historiográficas mais detidas. É o caso dos conflitos de jurisdição

\footnotetext{
3 Para um panorama geral de algumas das principais matrizes interpretativas sobre a questão: SOUZA; FURTADO $\mathcal{E}$ BICALHO, 2009.

4 Cujas primeiras formulações remontam ao século XVI pari passu àquelas sobre a chamada "decadência portuguesa" (CURTO, 2009, p. 188).

5 No Arquivo Histórico Ultramarino (AHU) que também preserva a documentação da Secretaria de Estado dos Negócios do Ultramar. Sobre a comunicação política entre o ultramar e o reino ver, entre outros: FRAGOSO $\mathcal{E}$ MONTEIRO, 2017.
} 
ou de precedência apresentados pelos oficiais régios, camarários e dignidades eclesiásticas ${ }^{6}$ e das representações das câmaras municipais, com toda sorte de arbítrios para o bom governo da república - que também poderiam constituir-se como ferramentas para expressão de queixas e denúncias contra um dado oficial ou conjunto de oficiais. ${ }^{7}$ Outras formas, contudo, são tomadas muitas vezes desde uma perspectiva generalizante e há, ainda, aquelas que, talvez por suas características mais protocolares, parecem não ter despertado muita atenção dos historiadores. O mesmo ocorre, de maneira ainda mais evidente, com a investigação dos caminhos e trâmites que tais tipologias percorriam no universo institucional do Conselho Ultramarino e as "respostas" que eventualmente provocavam.

O objetivo deste artigo é examinar alguns dos tipos de queixa a partir das quais os súditos do ultramar buscavam e muitas vezes logravam a intercessão do monarca e de seu Conselho Ultramarino frente às condutas antijurídicas dos oficiais. Explicar esses usos requer identificar suas conformações, considerando a "condição" de quem pedia, a forma a partir da qual se pedia, as razões pelas quais se pedia, os "remédios" efetivamente pedidos e, não menos importante, os procedimentos institucionais que suscitaram no Conselho Ultramarino - aspectos que podem, como argumentarei, ser, em boa medida, lastreados na sedimentação documental e arquivística da instituição.

Meu fio condutor está calcado, portanto, em formas de recurso e remédios que tinham ou poderiam ter em seu cerne querelas - no sentido amplo e geral de queixa, reclamação ou agravo $^{8}$ - contra os oficiais apresentadas pelos súditos do ultramar. Isso porque a historiografia luso-brasileira muitas vezes tende a reforçar a tese de que os mecanismos de controle do oficialato seriam, na prática, "ineficazes", bem como a ideia de que as queixas eram muitas, mas pouco se fazia sobre elas. Não obstante, uma investigação destes usos e formas mais específicas, além de evidenciar que as queixas poderiam, de fato, ativar distintos mecanismos de sindicância externa do oficialato, coloca em cena, o que me parece sobremaneira relevante, a existência de formas mais difusas de recurso e de controle sobre as condutas dos oficiais.

Nessa direção, explorando paralelamente os distintos caminhos de tratamento e decisão suscitados por diferentes tipos de queixume, a análise recai-

\footnotetext{
${ }^{6}$ E mesmo, como observado por STUMPF (2019, p. 6), as "dúvidas" apresentadas pelos oficiais que poderiam servir, também, para denunciar "erros/abusos de outras autoridades".

7 Para além, evidentemente, das expressões abertas de dissenso como os motins e revoltas.

8 Sobre o sentido geral de querela ver: GARRIGA, 2010, p. 326.
} 
rá, de um lado, em uma forma comum nas representações e petições de queixa propriamente ditas que assumiam os contornos de denunciações diretas e, de outro, nas petições fundamentadas em agravos por eles praticados no exercício de seus ofícios, que poderiam evocar diferentes "remédios" para amparo, proteção ou reparação de direitos injustamente agravados. Para tanto, parto do corpus documental do Conselho Ultramarino da segunda metade do século XVIII pertinente à capitania de Minas Gerais. O Império Português experimentava então uma série de transformações em seus "modos de governar". Contudo, uma mudança de paradigma político não seria de imediata consumação e, como buscarei demonstrar, o Conselho Ultramarino continuou a ter um papel relevante na recepção e tratamento das queixas e agravos. Quanto à Minas Gerais, embora suas particularidades sejam importantes ${ }^{9}$, a escolha desta capitania para tal abordagem se justifica por sua centralidade no seio do Império português e expressividade populacional no contexto, o que se traduz, também, em relevância arquivística, pois a incidência de diversos tipos de queixa permite tomá-la numa dimensão exemplar de formas que poderiam assumir e dos procedimentos adotados no Conselho Ultramarino.

\section{O Conselho Ultramarino: algumas considerações preliminares}

O Conselho Ultramarino foi, como se sabe, uma instância basilar de tramitação e tratamento da comunicação política entre os domínios ultramarinos e a administração central portuguesa na Época Moderna (CAETANO, 1969; BICALHO, 2012; CRUZ, 2015; LOUREIRO, 2018). Criado em 1642, no contexto da restauração, ao Conselho Ultramarino pertenciam "todas as matérias e negócios, de qualquer qualidade que forem"10 relativos ao ultramar, e a ele deveriam ser dirigidas todas as cartas e despachos enviadas pelos ministros, prelados e "quaisquer outras pessoas dos ditos Estados"11. Conforme um parecer do Procurador da Coroa dado em uma consulta de 14 de março de 1717, a instituição era, para os negócios do ultramar, “[...] Desembargo do Paço, Conselho da Fazenda, Junta dos Três Estados, Conselho de Guerra, e

\footnotetext{
9 Sobre as relações de autoridade estabelecidas entre os súditos do ultramar, os agentes da administração régia e o próprio rei ver os seminais trabalhos de SOUZA, 2007.

${ }^{10}$ Com exceção da provisão de Bispados e mais lugares e negócios eclesiásticos.

${ }^{11}$ Regimento do Conselho Ultramarino de 14 de julho de 1642, § 6 e 7 (CAETANO, 1969, p. 66).
} 
ainda em parte, Conselho de Estado [...]".12 Contudo, como era comum no seio da cultura jurisdicional, o monopólio do Conselho Ultramarino sobre "todas as matérias e negócios" das conquistas foi objeto de importantes controvérsias e embates que tinham em seu cerne batalhas entre diferentes agentes e organismos institucionais em torno do controle da comunicação política e do que Simona Cerutti (2018) denominou "mercado das petições".

De um lado, verificara-se, em diferentes momentos, uma série de conflitos de jurisdição entre a instituição e outros Tribunais e Conselhos superiores, a exemplo do Conselho de Fazenda, da Mesa da Consciência e Ordens e do Desembargo do Paço, ora decididos favoravelmente ao Conselho Ultramarino, ora não (CARDIM, 2005; BICALHO, 2012; CRUZ, 2015). De outro, inúmeras pesquisas já destacaram que, ao longo do século XVIII, as Secretarias de Estado assumiram, cada vez mais, competências e um lugar privilegiado no circuito da comunicação entre o ultramar e o reino (BICALHO $\&$ COSTA, 2017, p. 146). ${ }^{13} \mathrm{~A}$ isso se acresce, ainda, a significativa autonomia dos corpos políticos e a complexificação dos circuitos comunicacionais e de decisão no âmbito do próprio ultramar português. No que toca especificamente à problemática e ao recorte espaciotemporal aqui adotados, é bem provável que o Tribunal da Relação do Rio de Janeiro, criado em 1751, e as Juntas de Justiça, (re)estabelecidas a partir de 1765 em todos os lugares do Estado do Brasil que tivessem ouvidores, tenham passado a absorver, em alguma medida, demandas relativas às insatisfações e queixumes quanto à atuação ou inação dos oficiais, sobretudo, magistrados e eclesiásticos.

Não obstante, e a despeito destas ponderações, sabe-se que os Tribunais, Conselhos e autoridades superiores sediados em Lisboa continuaram a deter uma "forte centralidade política" (STUMPF, 2019, p. 3) durante toda a Época Moderna. Além disso, a prática dos corpos políticos e das partes de dirigirem-se omisso medio ao monarca apresentando queixas e agravos permaneceu recorrente na segunda metade do século XVIII. Mais que isso, nesse contexto, no Império português - assim como em outros espaços coetâneos - as imagens do soberano como "pai" e "protetor" das violências e vexações foram incidentemente reforçadas no bojo do pensamento reformista ilus-

\footnotetext{
12 BIBLIOTECA Nacional. Documentos históricos (doravante BN. Documentos históricos), 96, 1952, p. 228.

${ }^{13}$ É preciso destacar que há um importante debate historiográfico no que se refere especialmente ao papel das reformas pombalinas nessa viragem. Um panorama de alguns dos pontos de divergência pode ser consultado nas resenhas críticas publicadas pela e-Journal of Portuguese History, em 2007.
} 
trado. ${ }^{14}$ A ritualização do ato evidencia-se no próprio endereçamento desta correspondência dirigida especificamente ao monarca, ainda que seus autores soubessem que as demandas seriam filtradas e que não necessariamente chegariam às mãos do princeps. ${ }^{15}$

O Conselho Ultramarino também continuou a desempenhar um papel de relevo na recepção e tratamento de representações e petições que tinham em seu cerne queixas e agravos como atestam a série de livros de registro de suas atividades preservados no Arquivo Histórico Ultramarino. Convém, nesse sentido, introduzir alguns elementos fundamentais sobre sua organização, funcionamento e registro arquivístico.

Embora a atividade consultiva tenha chamado mais atenção dos historiadores, ela, em realidade, consistia em apenas uma parcela da atuação do Conselho Ultramarino. As consultas eram uma etapa passível ou não de ocorrer na tomada de decisão dos assuntos e negócios, a exemplo de outros organismos semelhantes, característicos dos sistemas polissinodais de governo do período (POLO MARTÍN, 2018). Concretamente, diversas ordens ${ }^{16}$ e provisões eram emitidas por expediente pelo Conselho Ultramarino, fossem destinadas à obtenção das informações para posterior consulta ou, propriamente, resoluções que prescindiam, segundo legislação régia ou o costume, da intervenção pessoal do monarca, sendo processadas de maneira autônoma pelos conselheiros. No século XVIII, o Conselho Ultramarino, assim como o Desembargo do Paço, era autorizado a fazer aquilo que José Subtil chamou de "utilização mais vantajosa de provisões", ou seja, a tomada de decisões ordinárias no que se refere a uma série de petições de graça em matéria de justiça (SUBTIL, 1992, p. 172). Particularmente relevante é o Alvará de 24 de julho de 1713, que determinava pertencerem ao expediente "negócios ordinários, e de menor entidade", com a declaração, contudo, de que nunca

\footnotetext{
${ }^{14}$ Cecilia Nubola (2002, p. 27) sugere, em seus estudos sobre os estados italianos, que ideia do soberano como protetor e pai atento atingiu sua expressão máxima no "iluminismo". Para o caso de Portugal, ver o levantamento de leis de: GOUVÊA PINTO, 1820, p. 286-287.

${ }^{15}$ No caso do Império português, como alhures, havia alvarás, leis e decretos que regulamentavam os "modos de falar e escrever". As endereçadas ao monarca se iniciavam invariavelmente com a fórmula "Senhor", sem outra coisa alguma (Alvará de 16 de setembro de 1597).

${ }^{16}$ Adoto aqui a nomenclatura "ordem" no sentido amplo, como utilizada no Conselho Ultramarino, embora seja importante destacar que elas poderiam assumir tipologias diplomáticas mais específicas como ofício, carta, carta régia, etc.
} 
deveriam ser despachados por menos de três ministros e que ficava "livre a cada um deles (não se conformando) pedir Consulta". ${ }^{17}$

Além disso, considero que a forma de registro dos papéis empregada pelo próprio Conselho Ultramarino é elemento de monta para compreensão de seu funcionamento e da tramitação da comunicação política. ${ }^{18}$ Em linhas gerais, há quatro grandes conjuntos documentais corporificados nos Livros de registro (Códices) de consultas: mistas, capitanias, partes e mercês gerais. ${ }^{19}$ A organização do registro das consultas, além disso, guarda alguns paralelos com os registros das "respostas", tomadas a partir de consultas ou não, ainda que estas também obedeçam, de maneira bem direta, às lógicas pertinentes à "matéria" e tipologia diplomática da resolução que originavam. Para os propósitos deste artigo, concentro a análise nos conjuntos documentais em que eram predominantemente registradas as consultas, quando o caso, e as respostas às representações e petições que versam sobre a problemática aqui proposta, quais sejam, "capitanias" (no caso "Minas Gerais") e "partes". ${ }^{20}$

Desde 1673, o Conselho Ultramarino manteve uma série de Livros de registro específicos para consultas e cartas régias, provisões e outras ordens correspondentes às capitanias do ultramar. ${ }^{21}$ Neles eram registrados aquilo que poderíamos chamar de matérias de governo, congregando arbítrios e temas relativos à administração dos territórios, conflitos de jurisdição e outras questões variadas alçadas à condição de pertinentes ao interesse geral, bem comum da república e "serviço real". Eram provenientes, em sua maioria,

${ }^{17}$ PORTUGAL. Alvará de 24 de julho de 1713. In: Collecção Chronologica de Leis Extravagantes, posteriores a nova compilação das ordenações do reino, publicadas em 1603. Parte II: Da Legislação Moderna. Coimbra: Real Imprensa da Universidade, 1819, p. 381

${ }^{18}$ Como já destacou Ana Canas Delgado Martins (2018), os livros de registro do Conselho Ultramarino apresentam "[...] conteúdos informativos nem sempre presentes na documentação avulsa [...]" e "[...] podem acrescentar informação ligada à tramitação administrativa e aos circuitos de decisão". Ver também: BOSCHI, 2018.

${ }^{19}$ Em nível mais amplo, estes atendiam a uma divisão mais simples: partes e mercês relativos ao "serviço de partes" e mistas e capitanias ao "serviço real". Essa subdivisão, pode ser observada em diversos requerimentos e consultas do Conselho Ultramarino sobre seu serviço. Ver, por exemplo: Livro de Registro de Consultas Mistas, Códice 26 (1754-1760).

${ }^{20}$ É comum encontrarmos em catálogos documentais e mesmo na historiografia uma proposta de subdivisão das consultas de "serviço real" e "partes" segundo à iniciativa, ou seja, "serviço real" as que baixavam ao Conselho e "partes" as que subiam oficiosamente ao monarca. Contudo, ao menos para a segunda metade do século XVIII, é possível encontrar consultas tanto que baixaram como que subiram nos códices de "consultas mistas" e nos códices de "consultas de partes".

${ }^{21}$ CATÁlOgO Geral dos Códices existentes no Conselho Ultramarino. Disponível em: https:// actd.iict.pt/view/actd:CUF006a001. Acesso em 10/01/2019. 
da correspondência mantida com os corpos políticos, nomeadamente das cartas e contas dos oficiais régios e dignidades eclesiásticas e das representações remetidas pelas câmaras municipais, sendo registradas também muitas das representações dos "Povos". As representações, das câmaras e dos Povos, eram a forma privilegiada, ainda que não exclusiva, de apresentação de um instrumento particular de recurso contra a atuação dos oficiais que discutiremos na primeira parte deste texto: as queixas que podem ser equiparadas às "querelas perfeitas" ou "denunciações de crimes públicos". Quando bem-sucedido, este tipo de queixa provocava na maior parte das vezes consultas e se desdobrava na averiguação in loco das ações e comportamentos arguidos a partir da abertura de devassas (especiais ou de residência). ${ }^{22}$

Já na documentação de partes ${ }^{23}$ eram registrados os trâmites e respostas dados ao que se designava propriamente de petição, uma tipologia documental específica formulada por indivíduos, grupos ad hoc ou mesmo oficiais régios ou eclesiásticos de caráter peditório sobre e em favor de questões relativas e próprias às suas necessidades, interesses, causas e direitos particulares - de "partes". Elas poderiam abarcar inúmeros aspectos da vida pessoal, funcional, econômica, jurídica e religiosa, incluindo-se, nesse escopo, como veremos na segunda parte, súplicas e requerimentos das partes, com frequência fundamentados em agravos, no sentido de direitos injustamente afetados (GARRIGA, 2010, p. 345), advindos da ação ou inação dos oficiais e que poderiam se desdobrar, por sua parte, em pedidos de diferentes "remédios" mais específicos. Alguns deles poderiam ser despachados por expediente pelo Conselho Ultramarino; outros exigiam intervenção extraordinária do monarca (e, com ela, consulta) para serem alcançados.

\footnotetext{
${ }^{22}$ Reforço que, embora não analisados especificamente neste artigo, os conflitos de jurisdição e os arbítrios das câmaras municipais que, como dito, também poderiam ter como fundamento querelas, eram registrados igualmente nos livros das "capitanias".

${ }^{25}$ No caso aqui em tela, os Códices de "consultas de partes" e os Códices de "ordens de partes" e de "provisões", residindo a diferença entre estes dois últimos na tipologia do diploma gerado. Os Códices de ofícios também se referiam à documentação das partes, mas estes, além de guardarem correlação mais direta no nível das consultas com as "mistas", registravam, sobretudo, provisões de serventias de ofício ou renovações, cartas de confirmação de doação de sesmarias, etc.
} 


\section{As queixas e o governo: "querelas perfeitas" ou "denúncias de crimes públicos"}

Comecemos por um tipo de queixa, que tramitava pelo Conselho Ultramarino, a partir da qual os súditos individual e coletivamente e, também, as câmaras municipais (até mesmo eventualmente outros oficiais), acusavam de maneira clara, direta e inconteste os oficiais que não satisfaziam devidamente o que se considerava legal e moralmente próprio de seu ofício. Ainda que fundamentadas em distintas tópicas e representações, essas queixas incitavam o papel do monarca como magistrado supremo e como superior temporal e autoridade máxima frente à qual todos os oficiais, de quaisquer natureza e condição, encontravam-se virtualmente subordinados à fiscalização e sujeitos a mecanismos de sindicância externa diretos, bem como a "punições" em virtude de comportamentos e ações menos conformes ao direito. ${ }^{24}$ Refiro-me, nomeadamente, a um tipo de queixa que, por suas características, pode ser equiparada às "querelas perfeitas" ou a "denúncias de crimes públicos"25, e que assumia, sobretudo, a forma dos tradicionais "capítulos" de denúncia. Embora mais conhecido pela historiografia ${ }^{26}$, convém esmiuçar com maior profundidade este recurso e seus caminhos no seio do Conselho Ultramarino.

Em termos processuais, as "querelas" eram definidas na literatura jurídica do período como delação feita em juízo competente de algum fato criminoso ${ }^{27}$ de gravidade em que os queixosos são obrigados a dar prova da sua queixa. Nas chamadas "querelas perfeitas", quem denunciava responsabilizava-se por nomear testemunhas e dar fiança, além de juramento, ao passo que as "querelas simples" eram a "queixa ou voz de alguém, sem o afirmar com juramento" nem dar testemunhas e fiança. ${ }^{28}$ Já as "denúncias" eram a declaração de um crime público feita em juízo competente para se proceder contra delinquentes por ofício da justiça, tendo lugar nos casos de devassa ou naqueles que as leis expressamente definiam ${ }^{29}$. Nas denúncias em casos

\footnotetext{
${ }^{24}$ Lembro que inúmeros oficiais detinham foro privilegiado assim como muitas causas, caso dos erros de ofício. Cf. PEREIRA E SOUSA, 1820, p. 5-10.

${ }^{25}$ A equiparação é depreendida de: FERREIRA, 1767, p. 173.

${ }^{26}$ Ver, por exemplo: CARDIM, 1998; SANTANA, 2012; ROMEIRO, 2017.

${ }^{27}$ Fato ilícito que infringe "a ordem civil em detrimento do público ou dos particulares", entendendo-se como fato também a omissão (PEREIRA E SOUZA, 1803).

${ }^{28}$ ORDENAÇÕES Filipinas: Livros IV e V. Reprodução "fac-símile" da edição feita por Cândido Mendes de Almeida, Rio de Janeiro, 1870. Lisboa: Calouste Gulbenkian.

${ }^{29}$ Como erros de ofício, blasfêmia, armas de defesa e peita.
} 
de devassa se exigia do denunciante a solenidade do ato de juramento, ao passo que, nos demais, também a fiança às custas, julgado e sentenciado, confundindo-se, nesse sentido, com as querelas dadas por pessoa do povo (PEREIRA E SOUSA, 1820, p. 37-38; FERREIRA, 1767, p. 172) - "querelas perfeitas" por exigirem testemunhas e fiança. Por isso, se aceita a equiparação, também no que diz respeito à via extrajudicial, tratava-se de um recurso caraterizado por um procedimento mais formalizado e rígido de apresentação, averiguação e resolução. E não era para menos. Como queixas ou denúncias que apontavam comportamentos e fatos considerados graves, muitas vezes propriamente crimes $^{30}$, perpetrados por um ou mais oficiais nelas acusados nominalmente e que detinham, nesse sentido, potenciais implicações processuais e punitivas, querelar omisso medio ao monarca era uma ação que envolvia uma série de ponderações, tanto por parte dos que denunciavam como daqueles que dariam encaminhamento à questão. A chave que operava aqui era a de autor(es), possíveis delitos e possível réu.

Essas querelas caracterizavam-se por narrações detalhadas de "fatos e culpas", por vezes dispostas textualmente em artigos ou capítulos, acompanhados da enumeração de testemunhas e remessa de documentos comprobatórios. Mobilizando recorrentemente em termos retórico-discursivos a amplificatio, o recurso, ainda que fosse também utilizado por partes, era mais comum em representações coletivas apresentadas em nome dos povos (com diversas assinaturas ou por procuração) e nas representações dos oficiais, particularmente, camarários - o que se traduz, também, em sua maior incidência de registro nos Livros de registro das capitanias do Conselho Ultramarino. Como exemplifica João Adolfo Hansen (2004) em seu clássico estudo sobre as práticas letradas coloniais, a utilização de expressões como "clamor geral", "miserável estado deste povo", "sentimento geral", "perigo de todo este Estado" efetivamente "hiperbolizavam o narrado". Estas concepções, conforme destacado por Pedro Cardim (1998), buscavam engrandecer as solicitações e "elevar estas causas mais ou menos particulares até um estatuto coletivo, mostrando que o 'bem comum' do reino estava em risco".

Seja em termos retórico-jurídicos ou pragmáticos, elas não eram apresentadas em virtude de um único agravo ou comportamento desviante - estes sempre amplificados - pois com elas se pretendia demonstrar a inaptidão generalizada do oficial suplicado para servir no ofício. A questão subjacente

\footnotetext{
30 Sobre a distinção entre "delito" e "crime" (PEREIRA E SOUZA, 1803). Para uma análise historiográfica (HESPANHA, 2015).
} 
era um "agravo" - poder-se-ia dizer - "coletivo", à medida que o bem comum e os pilares da conservação da república e do estado real estariam ameaçados pelos oficiais destituídos das qualidades e virtudes necessárias - males, conforme outro tópico incidente neste tipo de queixa, que seriam remediados pelo rei se devidamente informado das faltas. Era precisamente essa a ordem de ideias expressa pelos oficiais da câmara da cidade de Mariana que subscreveram, em 1775, os 21 capítulos de crimes públicos e particulares ${ }^{31}$, além das imoralidades, que, como afirmavam, eram praticadas pelo juiz de fora, o bacharel Antônio de Gouvêa Coutinho. Suas ações, alheias às suas obrigações e fruto de sua "[...] soberba, da avareza, da injustissa, e da falta de religiam [...]" eram prejudiciais "ao bem dos seus fidelissimos vassalos" e faziam o "[...] Ministro indigno do Real Serviço de V. M. por ser totalmente destituído de todas as circunstâncias que ornam um bom julgador"32.

Outro elemento importante dessa forma de queixa era que implicavam na averiguação in loco da verdade e suscitavam propriamente a ideia de castigo ou pena ao oficial em questão, seja a privação do ofício, a remoção do oficial do lugar ou outras punições em termos civis ou criminais. Os pedidos mais recorrentes eram para a nomeação de juízes comissários e ministros "desinteressados", encarregados de tirar devassas particulares (ou especiais) ${ }^{33}$ ou sindicância (residência). Para tanto, era preciso uma ordem régia especial para que algum desembargador devassasse ou sindicasse. Por isso, petições e representações de semelhante teor, se consideradas as acusações suficientemente graves e verossímeis, geravam na maior parte dos casos consultas, a partir das quais poderia se decidir pela nomeação (ou não) de ministros encarregados de conhecerem dos fatos relatados. Em caso afirmativo, era expedido um especial mandato régio ao ministro nomeado com as instruções devidas. Em suma: "querela perfeita" - consulta - ordem - devassa (especiais ou de residência).

As devassas especiais, particulares ou, ainda, de comissão eram um "mecanismo extraordinário" de controle dos oficiais (STUMPF, 2019) que resultava diretamente da prática de se apresentar queixas ao monarca e seus órgãos superiores e, ao que tudo indica, não se confundiam com as devassas de residência, já que o juiz comissário era encarregado de conhe-

\footnotetext{
${ }^{31}$ Sobre essa distinção ver: PEREIRA E SOUZA, 1803.

32 Arquivo Histórico Ultramarino, Avulsos de Minas Gerais (doravante AHU-MG), cx. 108, doc. 44.

${ }^{33}$ Cabe lembrar que no ordenamento jurídico português os monarcas poderiam ordenar a algum magistrado que tirasse devassas mesmo em casos que não fossem de devassa (PEREIRA E SOUSA, 1820, p. 28).
} 
cer dos capítulos e artigos da(s) queixa(s) que deram origem à comissão. ${ }^{34}$ Um exemplo desse trâmite é o que ocorreu com o bacharel José de Souza Monteiro, ouvidor da comarca do Rio das Mortes. Em princípios da década de 1750, os bacharéis Manoel José Correia e Alvarenga e Hilário Nunes da Mata Trant, per si e em nome de todos os habitantes da comarca, apresentaram 49 capítulos de "fatos e culpas" contra aquele ouvidor e seu "infame e escandaloso" procedimento ${ }^{35}$. Pediam, então, a nomeação de um desembargador da Relação do Rio de Janeiro encarregado de devassar ou sindicar àquele ministro. Em consulta do Conselho Ultramarino, a solicitação foi deferida, nomeando-se o desembargador da Relação do Rio de Janeiro, Inácio da Cunha Toar ${ }^{36}$, para tirar devassa particular do ouvidor. Nela, deveria conhecer dos fatos e culpas constantes nos capítulos, além de outros procedimentos apresentados ao Conselho Ultramarino pelo Bispo de Mariana ${ }^{37}$, pelo Intendente da comarca, pelo juiz ordinário de São João del Rey e pelos oficiais da câmara da vila de São José38 (que também geraram consultas). O resultado da diligência foi, além do sequestro dos bens do bacharel, sua prisão e pronúncia pelos crimes que cometeu no tempo em que serviu de ouvidor, sendo o mais grave deles o de barataria. ${ }^{39}$

Com efeito, as residências ou sindicâncias, mecanismo ordinário de controle do oficialato régio no universo luso (CAMARINHAS, 2012; ROMEIRO, 2017; MELLO, 2017), ao menos no caso do ultramar, poderiam ter essa forma de queixa como ato inaugural ${ }^{40}$, ainda que, nos pedidos, os supli-

\footnotetext{
${ }^{34}$ É o que se depreende do caso em questão. Os capitulantes do bacharel José de Souza Monteiro, após a devassa particular, requereram que também se tirasse residência geral do ouvidor para contemplar as queixas e capítulos não inclusos na devassa de comissão. AHU-MG, cx. 64, doc. 78. O próprio bacharel, anos mais tarde, requereu no Conselho Ultramarino a nomeação de um juiz sindicante para tirar residência. AHU-MG, cx.69, doc. 34 .

${ }^{35}$ Livro de Registro de Consultas de Partes, Códice 63 (1751-1753) (doravante Cód. 63, CP), p. 197198. Mais tarde, os mesmos Manoel José Correia e Alvarenga e Hilário Nunes da Mata Trant, apresentariam nova petição, em que se referiam a 75 novos capítulos. AHU-MG, cx. 64, doc. 78.

${ }^{36}$ Por isso, as "respostas" destas consultas devem ser rastreadas nos livros de ordens das capitanias, no caso daquelas relativas à Minas Gerais no período, no da capitania do Rio de Janeiro, local do Tribunal da Relação. Livro de Registro de Cartas Régias, Provisões e outras ordens para o Rio de Janeiro, do Conselho Ultramarino, Códice 229 (1739-1756) (doravante Cód. 229, O-RJ), p. 239.

37 AHU-MG, cx. 60, doc. 38; Livro de Registro de Consultas de Minas Gerais, do Conselho Ultramarino, Códice 244 (1726-1807) (doravante Cód. 244, C-MG); Cód. 229, O-RJ, p 241.

${ }^{38}$ AHU-MG, cx. 60, doc. 20; AHU-MG, cx. 60, doc. 33; Cód. 229, O-RJ, p. 239.

39 Cf. AHU-MG, cx. 68, doc. 31; AHU-MG, cx. 135, doc. 6.

${ }^{40}$ Segundo Nuno Camarinhas em suas análises sobre as residências no reino de Portugal o processo de residência era desencadeado, na forma das Ordenações, pelo magistrado, que era obrigado a comunicar a proximidade do termo do serviço, ainda que com a crescente
} 
cantes tendessem a demandar devassas particulares, tidas por muitos como mais eficientes que as residências. ${ }^{41} \mathrm{~A}$ partir das consultas do Conselho Ultramarino, o monarca poderia decidir pela nomeação de um sucessor para o magistrado suplicado e de um sindicante para sua residência. Assim ocorreu com o ouvidor de Vila Rica, Francisco Ângelo Leitão, em virtude de capítulos apresentados pelos moradores da cidade de Mariana em uma representação assinada por mais de 200 pessoas. Nela, queixavam-se de uma série de "opressões e violências" praticadas pelo ouvidor e pelo juiz de fora de Mariana, Silvério Teixeira, e clamavam por um remédio a estes males, expondo suas faltas "[...] em utillidade do bem commum, tanto do servisso de Deoz commo de Vossa Magestade [...]". ${ }^{42}$ Na consulta, os procuradores da Fazenda e Coroa e conselheiros do ultramar, reafirmando o papel das residências como meio "mais justo de se averiguar" as culpas dos oficiais régios, sugeriram que, visto ter acabado "o tempo porque foi provido" o ouvidor, o monarca poderia ser servido "aliviar aqueles Povos da opressão", nomeando um sucessor para ouvidoria, assim como um desembargador da Relação para tirar sua residência, prendendo-o se o achasse culpado e fazendo sequestro de seus bens. O mesmo ministro, deveria, ainda, conhecer dos capítulos sobre o juiz de fora, participando, neste caso, para posterior decisão, visto que, naquela altura, Silvério Teixeira já se achava despachado para o lugar de Provedor da Fazenda ${ }^{43}$. Nas devassas de residência tiradas pelo desembargador nomeado, Manoel da Fonseca Brandão ${ }^{44}$, ainda que se tenha verificado que algumas das assinaturas dos capítulos não haviam sido reconhecidas pelos signatários e que outras haviam sido dadas com propósito diferente ${ }^{45}$, o sindicado Francisco Ângelo Leitão foi pronunciado por culpas, entre outras, sobre emolumentos e salários - se "reputavam" de "venalidades" -, emitindo-se

burocratização, muitas vezes, a residência pudesse começar oficiosamente antes desse característico documento inaugural (CAMARINHAS, 2012, p. 166). No caso do Ultramar português identifiquei alguns casos em que querelas perfeitas (ou mesmo a afluência de queixas) foram o ato inaugural que provocou a substituição de oficiais régios, desencadeando residências.

${ }^{41}$ Até porque as residências e/ou a atuação dos juízes sindicantes, eram, per si, objetos de algumas das queixas. Ver, por exemplo: AHU-MG, cx. 73, doc. 69. Ver também: ROMEIRO (2017, p. 230).

${ }^{42}$ AHU-MG, cx. 73, doc. 69.

${ }^{43}$ Códice 242, Livro de Registro de Cartas Régias, Provisões e outras ordens para Minas Gerais, do Conselho Ultramarino (1753-1782) (doravante Cód. 242, O-MG), p. 53.

${ }^{44}$ Inicialmente foi nomeado o desembargador Ângelo Augusto Luiz Ribeiro, mas por seu impedimento, emitiu-se ordem a Manoel da Fonseca Brandão. Cód. 242, O-MG, p. 53.

${ }_{45}$ AHU-MG, cx. 73, doc. 69. 
ordem de prisão, além de sequestro de seus bens. ${ }^{46}$ Também resultou em culpas o conhecimento dos capítulos contra o juiz de fora, Silvério Teixeira. ${ }^{47}$

Claro está, nem sempre se considerava a representação ou petição suficientemente grave e verossímil para gerar uma consulta - que significava, concretamente, cogitar-se a ativação destes mecanismos de sindicância externa ordinários ou extraordinários - ou, ainda que, gerando consulta, fosse certo deferir-se aos pedidos. Nestes cálculos, para além dos fatos e culpas relatados, a "qualidade" do oficial em questão e a autoria e incidência de petições, representações e contas contra um mesmo oficial eram elementos ponderosos.

Quanto ao primeiro aspecto, há de se destacar que os magistrados régios parecem ter sido particularmente alvo deste recurso - sobre eles se concentra a maior parte tanto dos apresentados quanto dos bem-sucedidos, ao menos no que se refere às Minas Gerais da segunda metade do século XVIII. Já capítulos contra eclesiásticos ${ }^{48}$, por exemplo, suscitavam uma série de ponderações pela delicada relação entre as jurisdições régia e eclesiástica. Inúmeras das resoluções de "querelas perfeitas" (e de outras formas de queixumes e reclames) apresentadas contra párocos e vigários eram cartas régias de recomendação ao Bispo respectivo para que averiguasse e tomasse as providências necessárias ${ }^{49}$ - que, enquanto tais, poderiam ser despachadas por expediente do Conselho Ultramarino. Foi esse o destino da representação feita a D. Maria I pelos moradores da Vila de São João del Rey sobre as "desordens e escândalos" do vigário da freguesia, o bacharel Antônio Caetano de Almeida Vilas Boas, existindo nele "[...] como inato, o orgulho a mentira, a negociação, a uzura a lasciria publica [e uzo] e concelho de moral relaxada, praticando prejuro [calorado] com a amphebologia e restrição dos juram. ${ }^{\text {toz }}$ a q. vulgarm. ${ }^{e}$ chama emgrossão ideias [...]". Após a narração de seu "menos ajustado

\footnotetext{
${ }^{46}$ Cf. AHU, Avulsos do Rio de Janeiro (doravante AHU-CU-017), cx. 57, doc. 5520; AHU-CU-017, cx. 57, doc. 5521; AHU-MG, cx 74, doc. 21.

${ }^{47}$ Essas culpas geraram uma nova Consulta do Conselho Ultramarino. Cód. 244, C-MG, p. 162.

${ }^{48}$ No conjunto documental analisado até o momento identifiquei poucos casos de capítulos apresentados contra eclesiásticos embora contra eles fosse recorrentemente fundamentada uma outra forma que poderia assumir os queixumes: os arbítrios apresentados pelas câmaras municipais.

${ }^{49}$ Que, por sua parte, poderia resultar no conhecimento do negócio in loco com a nomeação pelo Bispo respectivo, por exemplo, de um visitador. Foi esse o procedimento empregado pelo Bispo de Pernambuco no conhecimento dos capítulos de queixa apresentados contra o vigário Antônio Mendes de Santiago, pároco da freguesia de Santo Antônio da Manga, comarca de Sabará, como se depreende da informação que deu ao Conselho Ultramarino. Cf. Livro de Registro de Consultas de Partes, Códice 67 (1763-1769), p. 54.
} 
procedimento", acompanhado das respectivas testemunhas, os capitulantes pediam o exame da verdade in loco por uma devassa de comissão para se ter a "providência" e "castigo" que o vigário merecia ${ }^{50}$. Obtiveram como despacho, contudo, uma carta de recomendação ao Bispo remetida via expediente. ${ }^{51}$

Quanto ao segundo aspecto, essas queixas também eram permeadas por uma avaliação relativamente rígida quanto à forma de apresentação e a autoria. Observemos a conta subscrita em 1754 pelo vereador mais velho da câmara de Mariana, Antônio Mendes da Costa sobre "[...] o lamentavel clamor q. vemos em todos os moradores desta Cidade, e seu termo, e o deploravel estado em q. esta comarca se acha [...]" decorrentes dos excessos cometidos pelo já mencionado ouvidor de Vila Rica, Francisco Ângelo Leitão. Ainda que recorrendo a inflexões da segunda pessoa do plural e a tópicas comuns nas representações feitas por oficiais camarários - como a participação ocorrer "por descargo de nossas consciências" - Antônio Mendes da Costa parecia estar ciente da gravidade de assinar a representação sozinho, quando era membro do corpo camarário, apresentando, de antemão, sua justificativa: a "[...] Camara receya q. este Menistro seja sciente desta rezolução, e q. na correyção fotura os cremine por vingança e lhes gloze as despezas" e que "p. ${ }^{a}$ buscarmos este dezafogo e cumprirmos com a nossa obrigação em rezão do Juramento q. tomamos, se nos faz precizo occultar esta de nosso Prezidente, q. não há de convir nella". ${ }^{52} \mathrm{Na}$ consulta provocada, na qual também se ponderou sobre uma petição coletiva dos povos de Mariana contra os mesmos procedimentos do dito ouvidor e "outras violências e opressões", o Procurador da Fazenda destacava, sobre a queixa do vereador, que "esta conta assinada por um só homem [...] não merece muita atenção", mas indicava que a queixa poderia ser reservada para que se tomasse conhecimento dela na residência, parecer acompanhado pelo Procurador da Coroa $^{53}$ e pelo Conselho. ${ }^{54} \mathrm{E}$, de fato, apenas por ocasião das novas queixas, que resultaram na ordem para a residência, é que as matérias apresentadas pelo vereador de Mariana seriam averiguadas. ${ }^{55}$

Todo o sucedido com o ouvidor de Vila Rica Francisco Ângelo Leitão ilustra, ademais, a inserção corrente das "querelas perfeitas" (ao que poderia

\footnotetext{
${ }^{50}$ AHU-MG, cx. 115, doc. 43.

${ }^{51}$ AHU-MG, cx. 115, doc. 43; Cód. 242, O-MG, p. 173.

${ }^{52}$ AHU-MG, cx. 66, doc. 11.

53 Que, contudo, ressaltava certa "verossimilidade" de algumas de suas partes

${ }^{54}$ Cód. 244, C-MG, p. 146-7

${ }^{55}$ Cf. AHU-CU-017, cx. 57, doc. 5520;
} 
se acrescer outros recursos) em "tramas coletivas" (STUMPF, 2019) que se corporificavam na apresentação de acusações ou, inversamente, de defesas dos oficiais. Sinais falsos ou dados com outro motivo, como identificado pelo sindicante no que se refere aos capítulos dos povos de Mariana, alianças e parcialidades locais, como as evidenciadas pela representação do vereador de Mariana ou, ainda, representações como a da câmara de Vila Rica, que afirmava que os capítulos apresentados contra o ouvidor Francisco Ângelo Leitão eram resultado da "prevercid. e de dois homenz cegos, e Irmaonz" que teriam fingido em nome do Povo ${ }^{56}$ são apenas algumas das facetas que poderiam assumir a corrente instrumentalização das queixas ao monarca nas lutas e disputas verificadas entre grupos de poder locais.

E, com isso, podemos percorrer outra característica fundamental deste tipo de queixa. No caso de terem sido apresentadas por partes ou pelos "Povos", para devassas particulares ou especiais, era preciso fazer previamente o depósito a título de fiança para as custas. ${ }^{57} \mathrm{O}$ valor depositado era devolvido apenas se o oficial suplicado fosse pronunciado na diligência e, mesmo se esta fosse feita em termos de residência, quando ordenada em virtude de capítulos, os signatários poderiam ter de arcar com parte das custas se não houvesse pronúncia ${ }^{58}$. Como resumia Manuel Ferreira Lopes (1767, p. 173), era justamente para precaver as calúnias que os "aulicos ministros da Mesa do desembargo do Paço" instituíram que sempre que capítulos fossem oferecidos contra os ministros dos lugares, seus oficiais, "ou pessoas de autoridade de governo", os capitulantes tinham que fazer depósito para satisfação das culpas. Caso contrário, "se não custa nada mais que a folha de papel que gastão", sempre que os oficiais não satisfizessem as vontades, logo se apresentariam capítulos, o que seria muito prejudicial à reputação dos oficiais e à justiça. Por outro lado, era usual o Conselho Ultramarino ordenar o sequestro dos bens dos oficiais que seriam submetidos a essas sindicâncias externas, pois, para além da satisfação de eventuais prejuízos causados no exercício do ofício, se fossem pronunciados, as custas da diligência seriam extraídas de seus bens.

\footnotetext{
${ }^{56}$ AHU-ACL, CU 003, cx. 17, doc. 1486.

${ }^{57}$ Disso decorrendo um elemento fundamental da equiparação às querelas perfeitas ou denúncias de crimes públicos que, em termo processuais, também exigiam a nomeação de testemunhas e fiança. (PEREIRA E SOUSA, 1820, p. 29). Ver também um interessante debate ocorrido no Conselho Ultramarino em 1665 sobre os capítulos contra o segundo vice-rei do Brasil (SANTANA, 2012, p. 126-127).

${ }^{58}$ Ver, por exemplo: Cód. 244, C-MG, p. 155
} 
Além disso, ainda que o procedimento ordenado quanto à averiguação pudesse variar de acordo com o caso, sempre havia a chance de os capitulantes serem integrados no conhecimento do negócio como autores ou testemunhas e terem de prestar juramento de calúnia, sob pena de condenação. E, acima de tudo, "mentir ao príncipe", apresentando queixas e denunciações falsas era crime prescrito nas ordenações (PEREIRA E SOUZA, 1803, p. 49). Portanto, para além de uma série de ponderações de ordem local - as "vinganças" - que muitos temiam, o ato de apresentar uma "querela perfeita" poderia acarretar perdas financeiras e outras penas, na ausência de pronúncia.

Veja-se o parecer do Conselho em uma consulta sobre a queixa apresentada, já em 1805, pelo tenente de milícias José Fernando de Sousa ${ }^{59}$ "por si e pelos mais vassalos e concidadãos" do Rio das Mortes, com diversas acusações contra o ouvidor Antônio José Álvares Marques da Costa e Silva, seu antecessor, José Antônio Apolinário da Silveira e escrivão de ambos, Caetano José de Almeida - e que não poupava nem gabinete real, implicando diretamente no enredo. ${ }^{60}$ Talvez por isso, desde um primeiro momento, a queixa suscitou desconfianças, como se nota da vista do Procurador da Fazenda: para ele, embora pudesse haver algum fato verdadeiro, "a maior parte continha uma insolente invectiva" e a própria consciência do queixoso já tomara seguro, ao pedir desculpas por sua "rusticidade natural".

Talvez no mesmo sentido - interessa destacar neste momento - é que, após idas e vindas, tomada de informações e inquirição do negócio, os conselheiros do ultramar, embora ponderando que alguns dos oficiais suplicados de fato não cumpriram plenamente seus deveres, consideraram suas faltas menores, ou sem dolo e malícia. A mesma compreensão não foi expressa quanto ao signatário da petição, cujo relato seria "em muitas circunstâncias particulares ou falsos ou adulterados" e sua representação "falta não só daquele respeito devido à magistrados do Trono, porém até destituída daquela lisura, sinceridade e decência, com que deve sempre a verdade ser presente ao Soberano". Por isso, para os conselheiros, José Fernando de Souza estaria a ponto de ser considerado um "falso denunciante, publicador de Libelos famosos, e ultimamente como mentindo ao Soberano em prejuízo de terceiro" e, portanto, sujeito ao que dispunham as Ordenações: custas, pena pecuniária e degredo para África. Já o advogado João da Silva Mourão, que pelas informações e diligências do ministro encarregado provava-se ser a cabeça

\footnotetext{
${ }^{59}$ A queixa baixou ao Conselho por aviso do Secretário de Estado dos Negócios do Ultramar. ${ }^{60}$ AHU-MG, cx. 175, doc. 28.
} 
por trás das acusações, deveria ser "capturado imediatamente, e mandado responder". Além disso, possivelmente sensibilizados com as feridas abertas pela Inconfidência Mineira, os conselheiros ainda sugeriram ser "muito conveniente" não ficarem ocultos aos "Povos das Minas" tudo o que fosse decidido sobre o assunto - afinal, era preciso "que a todos chegue a notícia de que assim como Vossa Alteza Real não tolera os excessos dos Ministros [...] também castiga asperamente os vassalos, que com público escândalo perturbam o público sossego, e se atrevem a mentir na Sua Real Presença." ${ }^{\text {61 }}$

Em resumo, as queixas equiparáveis às "querelas perfeitas" ou "denunciações de crimes públicos", mais ainda que outros recursos, por incidirem diretamente sobre a honra e a imagem dos oficiais, estavam indissociavelmente vinculadas à problemática da calúnia, o que mediava elementos fundamentais em termos de autoria e apresentação, tramitação e resolução. Elas eram, não obstante, uma forma de recurso importante para o controle do oficialato (SANTANA, 2012; ROMEIRO, 2017) e significativamente capazes de ativar os mecanismos ordinários e extraordinários de sindicância externa, no caso das Minas do século XVIII, especialmente quanto aos magistrados régios. Além disso, alguns dos casos enunciados demonstram que esses mecanismos não eram meramente protocolares e podiam, inclusive, gerar resultados desfavoráveis aos oficiais, para além da própria investigação que já poderia ser, por si mesma, uma consequência adversa.

\section{Os agravos e o serviço das partes: requerimentos e súplicas}

Na segunda metade do século XVIII, as "querelas perfeitas" ou "denúncias de crimes públicos" não foram a única e, tampouco, a mais recorrente forma a partir da qual os súditos das Minas Gerais - e de outras capitanias da América - apresentaram ao Conselho Ultramarino seus queixumes e reclames quanto às condutas oficiais. E isso não apenas pelas implicações que poderiam ocorrer caso a queixa se provasse falsa, mas porque as partes buscavam "remédios" diante dos erros, abusos ou inação dos oficiais que passavam, antes, por outros tipos de queixume e, de maneira conexa, de garantias de justiça. Além disso, não se pode perder de vista que, embora o ius puniendi seja, em nossas sociedades contemporâneas, o principal me-

${ }^{61}$ Cód. 244, C-MG, p. 231. 
canismo de controle, repressão e disciplina das condutas, assim não o era, em definitivo, nas sociedades de Antigo Regime (ARRIETA ALBERDI, 1996; HESPANHA, 1993; STUMPF, 2019).

No "serviço das partes", havia uma série de "remédios" ordinários ou extraordinários de garantia de direitos que poderiam ser pedidos e obtidos extrajudicialmente, via Conselho Ultramarino, no sentido de amparar, evitar, emendar ou satisfazer agravos cometidos por juízes, governadores, oficiais camarários, entre outros, no desempenho de seus ofícios - ou fruto de suas negligências. Isso porque querelas simples (no sentido de queixa) articuladas pelo interessado diante de agravos judiciais ou extrajudiciais eram a chave de diversas petições cujas respostas abundam nos Livros de registro de "ordens de partes" e "provisões" do Conselho Ultramarino.

Estas petições das partes não versavam sobre a inaptidão generalizada de um oficial para servir naquele ofício, mas sim sobre agravos específicos cometidos contra elas pelos oficiais (ou pelo receio de que assim o seriam), ainda que pudessem, também, servir estrategicamente para engrossar o coro de insatisfações mais amplas e que suas argumentações, por vezes, assumissem a forma de denúncias diretas ou capítulos. Tramitando como simples queixa, suplicação ou recurso, não seguiam necessariamente uma forma judicial, embora pudessem intervir no percurso processual ordinário de uma causa (GARRIGA, 2010). Aproximavam-se, em diferentes sentidos, de instrumentos como o "amparo colonial", comum no mundo hispano-americano, e a partir delas se requeriam diferentes "remédios" mais específicos. As bases do direito agravado poderiam ser mandatos régios a favor de uma pessoa ou grupo de pessoas ou, mais amplamente, as disposições teológico-jurídicas que previam ou regulavam direitos nessa sociedade (BARRAGÁN, 2000).

Concretamente, isso poderia se traduzir em pedidos pela intercessão régia de modo a impelir a autoridade (ou mesmo partes) a cumprir o que era conforme o "direito" do peticionário. O padre Francisco Dantas Coelho, vigário da freguesia de Guimarães, por exemplo, peticionou ao Conselho Ultramarino porque obtivera uma provisão régia para ser tutor de seus sobrinhos, mas, não obstante, o juiz de órfãos de Sabará "duvidava" entregar aos seus procuradores as pessoas e bens dos ditos órfãos ${ }^{62}$. Requeria, então, que, à vista do exposto, se ordenasse ao juiz de órfãos que cumprisse a dita provisão ou

\footnotetext{
${ }^{62} \mathrm{O}$ juiz de órfãos também representou ao Conselho Ultramarino, apresentando suas razões para não ter dado logo o cumprimento à provisão. AHU-MG, cx. 60, doc. 34.
} 
que se desvanecessem os motivos de sua recusa a cumpri-la. ${ }^{63}$ São também abundantes pedidos análogos em petições feitas por partes que ocupavam ofícios intermédios ou menores, nas quais se requeria que o monarca fosse "servido mandar" que as câmaras municipais e ouvidores pagassem ou restituíssem suas propinas e emolumentos, como se praticava de "estilos muito antigos $^{\prime \prime 64}$, ou para que fosse cumprido o determinado em suas provisões de provimento, o que ocorria, de modo geral, em virtude de recusas atribuídas às inimizades e oposições existentes entre aquele que pedia e os que deveriam cumprir. E, ainda, pedidos diretos de declaração ${ }^{65}$ de algum direito que os peticionários considerassem ter. Nesse sentido, Francisco Antônio de Mendonça, antigo escrivão da Intendência e conferência de São João del Rey, requeria que o monarca fosse "servido declarar" que àquele ofício competia todo o processo cível e crime e a escrita de que as partes deviam pagar salários e, ainda, que se ordenasse que o escrivão da receita se abstivesse e o restituísse "sem embargo de qualquer oposição". Argumentava então que, a despeito das ordens régias e dos regimentos, fora "privado" de regalias do seu ofício e "gravado" em direito em virtude dos "despotismos" do escrivão da receita, com fundamento em uma ordem do governador da capitania. ${ }^{66}$

Quando deferidas, petições como estas podiam gerar precedentes, mais tarde mobilizados por outros sujeitos que ocupassem o mesmo ofício ou se encontrassem em situação equiparável. ${ }^{67}$

As petições de "graça em causa que à justiça possa tocar", embora sejam normalmente associadas pela historiografia às competências do Desembargo do Paço, tramitavam fartamente no Conselho Ultramarino no "serviço das partes". Segundo Antônio Manuel Hespanha, a "graça em matéria de justiça" congregava casos que alteravam situações jurídicas, a partir da dispensa das leis (cartas de privilégio), e casos que recaíam no exercício do "poder discricionário do rei" (cartas de benefício) ou que versassem sobre a situação dos funcionários de justiça (HESPANHA, 1982, p. 337, 361-364). E muitos dos remédios que ela abarcava, formalizados especificamente para tanto ou não, eram pedidos pelos peticionários para o amparo ou reparação de um direito que fora

\footnotetext{
63 AHU-MG, cx. 60, doc. 34. Livro de Registro de ordens de partes, do Conselho Ultramarino, Códice 194 (1754-1758) (doravante Cód. 194, OP), p. 64.

${ }^{64}$ Ver, por exemplo: Livro de Registro de ordens de partes, do Conselho Ultramarino, Códice 193 (1746-1750) (doravante Cód. 193, OP), p. 293

${ }^{65}$ No sentido que "declarar o direito" tinha naquele contexto (CLAVERO, 2006, p. 5).

66 AHU-MG, cx. 95, doc. 5; Códice 195, OP, p. 146.

${ }^{67}$ Códice 193, OP, p. 293; Códice 194, OP, p. 225, 226; Códice 195, OP, p. 173; AHU-MG, cx. 101, doc. 29
} 
negado ou agravado indevida e injustamente pelas autoridades no exercício de seus ofícios. Em outros termos, a "graça em matéria de justiça", embora não necessariamente envolvesse agravos decorrentes de condutas antijurídicas dos oficiais, abarcava inúmeros "remédios" pedidos muitas vezes em virtude delas.

Como a própria nomenclatura sugere, muitos inseriam-se nos marcos de início, andamento ou reforma/revisão de processos e sentenças. De imediato, era o caso de algumas das provisões para poder citar em libelos cíveis juízes e oficiais camarários, sem embargo das leis em contrário. ${ }^{68}$ Trata-se do caminho utilizado pelo médico assistente na Vila de São João Del Rei, Antônio Tavares da Rocha, diante da recusa dos oficiais que serviram na câmara em 1769, "com pretextos frívolos, afetados, e menos verídicos", que se recusavam a cumprir e executar a provisão régia que aprovara seu partido. Diferentemente de outros médicos em igual situação que pediam ordens régias para impelir as câmaras a efetuarem o pagamento, pretendia "[... p. ${ }^{a}$ livrarse desta opressão, e violencia [...]", demandar e executar a câmara perante o ouvidor da comarca. ${ }^{69} \mathrm{O}$ mesmo Manuel José Correia e Alvarenga, signatário dos capítulos apresentados contra o ouvidor da comarca do Rio das Mortes, José de Souza Monteiro, também peticionou individualmente em razão do que considerava ser uma "cega suspensão" de seu exercício das letras promovida por aquele ouvidor sem outra causa, como argumentava, que a de impedi-lo de impugnar a feitura de uns segundos pelouros e eleições para as câmaras da comarca, que haviam sido determinadas pelo magistrado régio com "desordenados, e estranháveis fins". Pedia, então, licença régia para poder citá-lo e demandá-lo pelas perdas e danos que lhe ocasionara com aquela suspensão. ${ }^{70}$

Solicitações para que capítulos fossem admitidos nas residências embora o peticionário estivesse preso ${ }^{71}$, para avocação de autos ou nomeação de juízes comissários ${ }^{72}$, cartas tuitivas, pedidos para que os pleitos das partes corressem apenas diante de determinado juízo ${ }^{73}$ também eram embasados, não raro e de maneira bastante direta, em "agravos" resultantes de condutas antijurídicas dos oficiais. Era o caso de Sebastião Marques de Carvalho, mo-

\footnotetext{
${ }^{68}$ Alguns exemplos: AHU-MG, cx. 61, doc. 19; AHU-Rio de Janeiro, cx. 53, doc. 7; AHU-MG, cx. 99, doc. 28; Livro de Registro de provisões do Conselho Ultramarino, Códice 102 (1750-1755), p. 104, 105; Cód. 195, OP, p. 160.

${ }^{69}$ AHU-MG, cx. 99, doc. 28; Cód. 195, OP, p. 160

${ }^{70}$ AHU-MG, cx. 61, doc. 19; Cód. 102, Provisões, p. 104, 105.

${ }^{71}$ Cf. AHU-MG, cx. 66, doc. 53; Cód. 194, OP, p. 100;

72 AHU-MG, cx. 68, doc. 39; Cód. 103, Provisões, p. 75, 76.

75 AHU-MG, cx. 56, doc. 56; Cód. 193, OP, p. 293.
} 
rador na vila de São José que pedia provisão para ser citado e demandando apenas perante as justiças de Sabará, Vila Rica ou Mariana, “[...] pellas justiças daquelle citio lhe serem oppostas, ficando por este principio gravado, não só na fazenda; mas taobem na pessoa [...]."74 Ou do padre Feliciano Pita de Castro que pedia uma carta tuitiva conservatória e restituitória para ser mantido, "sem perturbação", na posse da sua igreja, ameaçada pelas investidas de um vigário encomendado "intruso pelo Cabildo do referido Bis-

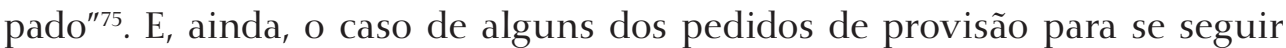
apelações ou agravos ordinários. José Alves da Costa, por exemplo, pedia uma provisão para poder prosseguir sua apelação sem embargo ter passado o tempo. A razão era que o Intendente da comarca do Rio das Mortes, juiz da causa, deveria lhe assinar tempo útil e conveniente por frotas, "como se pratica em todas as apelações que vem do Ultramar", mas este lhe assinara apenas o tempo da lei, findo o qual julgara a causa por deserta e não seguida, sendo, portanto, restringindo de alcançar sua justiça. ${ }^{76}$

A maior parcela das petições do serviço de partes deste gênero era despachada ordinariamente no expediente do Conselho Ultramarino, gerando ordens, provisões ou ambas, a depender do caso e remédio específicos pedidos e/ou concedidos. Assim, a petição de João Teixeira de Souza para se lhe entregar as legítimas de seu neto órfão Feliz Gomes de Souza, que se achavam dadas no juízo de órfãos a várias pessoas "sem as seguranças necessárias" provocou, além de uma ordem de informe, uma provisão para a entrega das legítimas ao peticionário e uma ordem dirigida ao ouvidor da comarca do Serro Frio, a ser registrada no livro competente "para constar o que por ela determino". Nela era-lhe declarado que, consistindo uma das principais obrigações do cargo em "vigiar sobre arrecadação dos bens dos órfãos" deveria, assim como "vossos sucessores", examinar os livros e prover para que os bens fossem administrados com segurança. ${ }^{77}$

Mas havia muito mais. Diversas petições eram apresentadas em busca de "remédios" que careciam de intervenção especial do monarca como "senhor da graça", a exemplo das revistas e pedidos de segunda devassa, concedidas apenas via consulta. Foi essa a petitio de uma das súplicas apresentadas pelo capitão Heitor de Sá Sotomaior e outros moradores da Vila de

\footnotetext{
${ }_{74}$ AHU-MG, cx. 56, doc. 56; Cód. 193, OP, p. 293.

75 Cód. 195, OP, p. 154.

76 AHU-MG, cx. 68, doc. 53; Cód. 103, Provisões, p. 81

77 Códice 241, O-MG, p. 341; Códice 101, Provisões, p. 296.
} 
São João del Rey, "possuidores" de umas terras e águas minerais das quais haviam sido espoliados "violentamente" e por meio de "assuada" e "motim". Segundo o relato, o ouvidor da comarca, o bacharel José de Souza Monteiro, sem "tomar conhecim. ${ }^{\text {to }}$ algum do tal levante" concedera aos seus cabeças, presos por ordem do governador da capitania, alvará de fiança, "sendo público" que um deles saía da cadeia a noite para falar com o mesmo ouvidor. ${ }^{78}$ A "paixão" com que favorecia os suplicados "delinquentes" era detalhada, ainda, pela exposição de uma série de outras irregularidades e injustiças que teriam ocorrido na condução da devassa tirada sobre o episódio, que incluía desde despachos "aéreos e alheios" aos requerimentos dos suplicantes até a admissão apenas das testemunhas que haviam sido nomeadas pelos "mesmos insultorez".79 Insinuavam, então, a nulidade da devassa em virtude da suspeição do juiz e do suborno (fundamentos das revistas), pedindo a nomeação de um desembargador desinteressado, às suas custas, para tirar segunda devassa, de modo que não ficassem os suplicantes prejudicados e tampouco os delinquentes sem castigo. O pedido foi deferido em uma consulta do Conselho Ultramarino, ordenando-se ao desembargador da Relação encarregado de conhecer os capítulos de queixa contra o ouvidor, que averiguasse também esta "matéria" e "achando que é como os suplicantes dizem procedais a nova devassa pronunciando e prendendo os culpados". ${ }^{80}$

Nestas petições apresentavam-se recursos extraordinários nos quais graças especiais ou especialíssimas eram pedidas, por exemplo, como remédio subsidiário e extraordinário em casos de notória opressão, ou força ou por não guardar o direito natural (GOUVÊA PINTO, 1820, p. 288). Vejamos a súplica do alferes de dragões Valério Sanches Brandão, preso da cadeia de São João del Rey por ordem do governador de Minas Gerais em virtude de sua atuação por ocasião de um levante ocorrido na região de Jacuí e que tinha em seu cerne um conflito de jurisdição entre os governadores das capitanias de Minas Gerais e de São Paulo. O alferes relatava que, cumprindo estritamente as ordens que recebera do anterior governador, Luís Diogo Lobo da Silva, que lhe ordenara prender todas as pessoas que quisessem se sujeitar à capitania de São Paulo, e do que então servia, o Conde de Valadares, que recomendara a observância das ordens anteriores, acabara prendendo o juiz ordinário, Tomás José Pinto Adorno França, e o almotacel, Vicente Vieira da Mora. Mas,

\footnotetext{
${ }^{78}$ AHU-MG, cx. 61, doc. 17

79 AHU-MG, cx. 61, doc. 17; AHU-MG, cx. 62, doc. 16

80 AHU-MG, cx. 62, doc. 16; Códice 63, OP, p. 219; Cód. 229, O-RJ, p. 242.
} 
como os governadores "costumão desculparem-se com [excessos]" daqueles a quem cometiam suas ordens, caíra no desgosto do Conde de Valadares, sendo "castigado, e injuriado [...] com extraordinario excesso". Nomeadamente, o governador ordenara sua prisão e que não fosse mais pago do soldo que tinha vencido, aplicando-lhe "[...] sem mais sentença, e sem o suplicante ser ouvido duzentas oitavas [...]" para satisfação da injúria ao juiz e almotacel; mandou, ainda, que o ouvidor da comarca devassasse ou fizesse sumário do suplicante, o que este assim praticou, citando-o preso. E se provaria mais que o "Governador não castiga como juis recto", pois, remetendo-lhe certidões que comprovariam que não fizera as prisões "com dolo" ou "malícia" e que os que havia prendido eram "cabeças de motim", o governador lhe negava a entrega dos documentos, impedindo-lhe, assim, sua defesa "q. hé de direito natural". Em suma, suplicava que o monarca ordenasse ao governador que lhe passasse as certidões para a sua defesa (sendo necessário), que o soltasse e mandasse pagar os soldos vencidos, bem como que fosse conservado no posto até sentença final, atendendo tanto a sua inocência como a ter servido à "Vossa Majestade" "muitos annos sem nota", destacado por "toda a capitania com o trabalho que se sabem tem os soldados das Minas [...]".81

Cabe ainda destacar contudo, que embora estejamos falando da via extrajudicial de atuação do poder régio, isso não significa que se tratava de resoluções (via expediente ou consulta) que dispunham arbitrariamente do direito e, tampouco, de decisões meramente discricionárias - até porque o governativo ou gracioso poderia se comutar em contencioso caso agravassem direitos de terceiros. ${ }^{82}$ Do ponto de vista dos procedimentos, havia no Conselho Ultramarino, evidentemente, matérias e ocasiões que, via expediente ou com consulta, tomavam-se decisões imediatas. ${ }^{83}$ Não obstante, como organismo concelhio típico de governo polissinodal, em que prevaleciam as razões de prudentia e iustitia - e apesar das transformações nesse modelo de governo já amplamente discutidas para segunda metade do século XVIII - era comum expedir-se as chamadas "ordens de informe" dirigidas ao oficial arguido ou a outros que pudessem informar com seu parecer, as

\footnotetext{
${ }_{81}$ AHU-MG, cx. 103, doc. 57; AHU-MG, cx. 107, doc. 2.

${ }^{82}$ Assim como o contencioso poderia comutar-se em governativo (GARRIGA, 2008).

${ }^{85}$ Confirmações de doação de sesmarias, tutelas de órfãos concedidas às mães, alvarás de mantimento, ajudas de custo, entre outras. Já no que se refere aos recursos que poderiam ter em seu cerne queixumes e reclames, encontram-se na mesma situação por exemplo, licenças para citar e demandar oficiais, as quais eram concedidas em sua maioria sem as antecedentes ordens de informe, embora aqui também pudessem ocorrer.
} 
quais poderiam implicar em diligências judiciais ou extrajudiciais a serem feitas pelas autoridades locais. ${ }^{84}$ Além disso, quando não precedidas de informes e pareceres, não era inusual incluir-se "condições" nas ordens e provisões expedidas via expediente ou consulta, a exemplo de "sendo verdade" ou "não achando ou engano no fato ou inconveniente"

Isso é em tudo condizente com o que tenho aqui argumentado. Como queixumes e reclames pela ação ou inação de algum oficial embasavam muitos dos "remédios" pedidos no Conselho Ultramarino, não é de surpreender que também fosse de "justiça" averiguar nestes casos a verdade (ainda que em termos diversos daqueles das "querelas perfeitas") ouvindo o oficial que, se depreendia, tivera alguma conduta antijurídica, assertiva ainda mais válida para os casos considerados graves ou quando o "remédio" implicava uma intervenção de cariz mais extraordinário. ${ }^{86}$

Para se conseguir a devida averiguação da verdade nesta matéria, e se poder ela resolver com a necessária audiência das partes, pelo modo com que em semelhantes circunstâncias se costuma praticar; deve-se passar as ordens para que sobretudo informe com o seu parecer [...] [grifo meu]. ${ }^{87}$

Essa foi a opinião do Procurador da Fazenda na vista que deu àquela petição do alferes Valério Sanches Brandão, preso por ordem do governador e privado de seus soldos e posto. O despacho do Conselho foi que os governadores de Minas Gerais e de São Paulo, envolvidos na contenda que resultara na prisão, informassem sobre a "súplica". ${ }^{8}$ Mais tarde, o alferes apresentou nova petição ao Conselho Ultramarino. Nela, relatando novamente o ocorrido, acrescia um dado de relevo: obtivera na Relação do Rio de Janeiro sentença e alvará de soltura, mas, ainda assim, continuava preso. Agora, a súplica (termo mais vinculado aos "atos de graça") passara a requeri-

\footnotetext{
${ }^{84}$ Para uma abordagem geral do tema: HESPANHA, 2010; CLAVERO, 2006. José Subtil (1998, p. 147-148) em suas análises sobre o Desembargo do Paço também sinaliza que a prática de pedir informação ou parecer à administração periférica era corrente naquele Tribunal.

${ }^{85}$ Esclarecedor nesse sentido: AHU-MG, cx. 69, doc. 24; Códice 65, CP, p. 193; Livro de Registro de ofícios do Conselho Ultramarino, Códice 141, p. 68. Note-se, ainda, a particularidade do registro dessa resposta.

${ }^{86}$ Lembro, nessa direção, que a própria graça podia ser dispensada de forma similar à como se administrava a justiça: "esto es, a instancia de parte y mediante procedimientos de audiencia y escrutinio" (CLAVERO, 2006, p. 9).

${ }^{87}$ AHU-MG, cx. 107, doc. 2

${ }^{88}$ Cód. 195, OP, p. 208.
} 
mento (vocábulo mais vinculado à "justiça") no linguajar dos conselheiros. ${ }^{89}$ Nova ordem de informe foi despachada via expediente, mas, desta vez, com a cláusula de que, "não dando outro motivo para a prisão do suplicante o mandeis soltar vista a sentença que obteve da Relação". ${ }^{90}$ Note-se, ainda, como o caso é apresentado simultaneamente em diferentes instâncias, Tribunal da Relação e Conselho Ultramarino, demonstrando não apenas a recorrência a diferentes estratégias por parte do peticionário, mas também a fluidez da causa, passando de extrajudicial à judicial, de judicial à extrajudicial, de seu princípio ao fim.

Era uma situação bem diversa da de Maria Carvalha da Silva, mulher branca, pobre e moradora na Vila de Guaratinguetá, capitania de São Paulo. Ela recorreu ao Conselho Ultramarino em busca de uma provisão para que o ouvidor da comarca do Rio das Mortes, capitania de Minas Gerais, fizesse um auto de corpo de delito com testemunhas, procedesse a devassa e prendesse João Gomes do Nascimento, morador em São João del Rey, que teria muitos anos antes assassinado seu marido naquela vila. Da petição, depreendia-se a negligência das justiças locais, já que seria "público" que seu marido fora "morto" pelo suplicado, que, juntamente com sua mulher, teria, ainda, se apossado dos bens da vítima. E "[...] como naquela comarca se não tirou devassa, talvez por se fazer o suplicado poderoso com aquela usurpação, e morte tirana, traidora, e aleivosa [...]", buscava uma provisão ordinária para que o ouvidor da comarca conhecesse do crime, embora fundamentasse todo seu pedido na sua condição jurídica de viúva e pobre, fortalecendo com isso em termos retórico-jurídicos seu pedido. O Conselho Ultramarino, em concordância com a vista do procurador régio, considerou, diante dos muitos anos passados desde que ocorrera o crime, ser "justo mandar-se primeiro que sobretudo informe o ouvidor". Mas também aqui foi inserida uma cláusula: a informação deveria ser dada "com toda a especificação exação precisas para a completa averiguação da verdade procedendo a quantas diligências julgardes condizente a esse fim".91

Talvez, neste caso, assim como em outros com despachos similares, a própria ordem de informe, com "condição" ou não, pudesse impelir as autoridades locais em favor do que se pedia, sem com isso colocar-se os oficiais

\footnotetext{
${ }^{99}$ Destaca-se, não obstante, como já sinalizaram Nuno Monteiro e Francisco Cosentino (2017, p. 434), que não havia, nesse universo, uma radical separação entre as matérias de graça e as da justiça.

${ }^{90}$ Cód. 195, OP, p. 231. E assim de fato se praticou. AHU-MG, cx. 108, doc. 20.

${ }^{91}$ AHU-São Paulo, cx. 6, doc. 9; Códice 195, OP, p. 235.
} 
em uma situação delicada de repreensão, facultando-lhes a possibilidade de atender sob capa de realizar a vontade régia, como já sugeriu Russel-Wood (2000) em suas análises sobre petições extrajudiciais no Império Português. Ainda nessa direção, é preciso ter em vista que a prudentia e a iustitia no tratamento de queixumes que envolviam os oficiais, independentemente de suas formas mais específicas, era também basilar para preservação da moral e autoridade destes oficiais e para evitar-se intervenções que colocassem em jogo os delicados equilíbrios locais - o que, como se sabe, poderia ter amplas consequências, sobretudo, no ultramar. ${ }^{92}$

Atalhar as delongas destes trâmites, assim como indicações sobre oficiais aptos a informar sobre a verdade era, aliás, tema presente em inúmeras petições das partes - cuja resolução final, como todas as mais tramitadas pelo Conselho Ultramarino, poderia demorar anos e anos entre muitas idas e vindas dos papéis e pessoas pelo atlântico. Era precisamente o que pretendia Lopo Teixeira em um dos recursos extraordinários que apresentou ao monarca com o intuito de ter restituídos seus bens, escravos e sua mulher, os quais, alegava, haviam sido retirados dele pela execução sumária feita pelo bacharel Antônio dos Reis, quando Intendente da comarca, em conluio com seu sogro, Manoel Dias Correia. Após passados anos da primeira petição que apresentara, quando recebera um despacho para que o governador informasse ouvindo o ministro arguido, o peticionário recorria novamente ao rei. Na ocasião pedia que, ainda que não tivesse "dúvida" que o bacharel fosse ouvido "[... por ser verd. ${ }^{\mathrm{e}}$ solida tudo o q expoem na sua . $^{\mathrm{m}}[$ [...]":

O mizeravel supp. ${ }^{\text {te }}$ nesta consternação não teve outro remedio mais q padecer hua tão cruel jornada . $^{\text {a }} 2^{\mathrm{a}}$ vez se abrigar aos Reaes pes de V. Mag. ${ }^{\text {de }}$ recorrendo com $2^{\mathrm{a}}$ suplica q vindo remetida ao Cons. ${ }^{\circ}$ Ultra. $^{\circ}$ nella se proferio o desp. ${ }^{\circ} \mathrm{q}$ informasse o Gov. ${ }^{\text {or }}$ sem

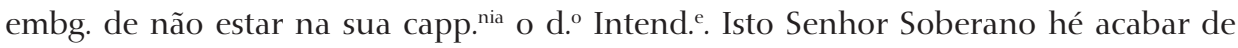
comcluir de todo o aflito, e pobre supp. ${ }^{\text {te }}$ vassalo de V. Mag. ${ }^{\text {de; }}$ q como seu Rey e Sr. o deve favorecer por justiça e mizeria [danificado] porq sendo [já duas] as jornadas das minas havendo $3^{a}$ nella acabara a vida pello dilatado dos annos, falta de meyos, e ate precizo sustento por padeser as mais notaveis necessidades, motivo estes por $3^{\mathrm{a}}$ vez recorre a innata piedade de V. Mag. ${ }^{e}$ pedindo-lhe pelas chagas de N. Sr. Jesus Christo, e pela pureza de Maria Santissima seja servido ordenar ao Cons. Ultr. ${ }^{\circ}$ q junta esta suplica aos mais papeis do supp. ${ }^{\text {te }}$, e se lhes parecer ouvir o Intend. ${ }^{\mathrm{e}} \mathrm{q}$ se acha na R. ${ }^{\mathrm{am}}$ do Porto

\footnotetext{
${ }^{92}$ Sobre a "consciência" das autoridades portuguesas quanto ao perigo de sublevação nas colônias, bem como sobre as especificidades do significado "do mando" no Império português, particularmente no que se refere às Minas Gerais do século XVIII, ver: SOUZA, 2011.
} 
servindo a V. Mag. ${ }^{\text {e }}$ consulte com effeito o requerim. ${ }^{\text {to }}$ p. $^{\text {a }}$ este ser deferido como a real

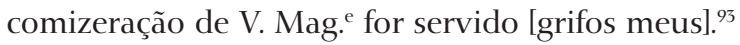

Lopo Teixeira recorria então ao monarca a partir de dois fundamentos comuns nas súplicas, quais sejam, como "pai" - figura especialmente vinculadas às tópicas retórico-jurídicas dos "pobres", "miseráveis" ou "rústi$\cos ^{\prime}$, dignos de uma atenção especial ${ }^{94}$ - e como "Rei e Senhor", ou seja, não por via de jurisdição (CASTRO, 1742, cap. 4). Assim, pedia que o Conselho Ultramarino consultasse de modo a alcançar algum remédio para reparar a violência contra ele praticada, esperando-o da inata piedade e comiseração do soberano. Na prática, diante das circunstâncias que expunha, o pedido era para que sua petição não seguisse o procedimento costumeiro em casos semelhantes, seja no que toca à tramitação no Conselho ou propriamente à suspensão da execução que resultara na perda de seus bens, objetivo último do peticionário. Sua insistência surtiu efeito, ao menos parcialmente. De fato, ocorreu uma consulta sobre suas súplicas, mas esta teve lugar apenas após a informação dada pelo ex-Intendente. Quanto a seu propósito final, o voto do procurador da fazenda foi contundente: embora se reconhecesse violento o modo da "sumaríssima execução" no sequestro e venda dos bens, se tratava, dizia o Intendente, de forma costumada e que mandava o regimento, e, ainda que não constasse no Conselho Ultramarino que este tivera aprovação régia, “[...] bastava para senão haver de anular logo a mesma execução, e se rescindir por um meio extraordinário, em que sempre se vinha a determinar contra o direito do rematante, sem ser ouvido [...]. A solução, indicada pelo procurador e pelos conselheiros, era a de que não tinha lugar a intervenção extraordinária pedida pelo suplicante, que devia usar dos meios ordinários para que, na superior instância, ouvidos os interessados, se determinasse como fosse justo. Para tanto, contudo, como se passara muitos anos desde a execução, decidiu-se conceder-lhe uma provisão de dispensa do lapso de tempo para que pudesse apelar ordinariamente do sequestro e execução feitos pelo Intendente.95

\footnotetext{
${ }_{93}$ Resgate Avulsos (BG). AHU_CU_003, cx. 16, doc. 136.

${ }^{94}$ Os rústicos eram tidos como dotados de especificidades de maneira que não seria possível a aplicação estrita do direito comum (HESPANHA, 2011).

${ }^{95}$ Livro de Registro de consultas de partes do Conselho Ultramarino, Códice 66 (1756-1758), p. 91.
} 


\section{Considerações Finais}

Tudo isso coloca em cena a existência de um amplo e multifacetado canal institucional que ganhava corpo naquilo que alguns autores denominam "sistema petição e resposta" (MASTERS, 2018). Por meio dele, os súditos do ultramar de diferentes condições sociais e status, coletiva ou individualmente, a partir das câmaras municipais ou por si próprios, em nome do "bem comum" ou em favor de seus "direitos" particulares, mobilizavam ativamente, com suas queixas e agravos, o Conselho Ultramarino e, eventualmente, o próprio monarca, além de outros agentes chamados a informar ou averiguar.

Lançando mão dessa via, o Conselho Ultramarino continuou a desempenhar, na segunda metade do século XVIII, uma não desprezível atividade de controle, ou ao menos de tutela e disciplina, sobre o oficialato, e exerceu um papel basilar de "garantista" na proteção de "direitos" - ao menos no que se refere à capitania de Minas Gerais. Se as queixas e agravos eram, de fato, muitos, uma análise mais detida de suas formas e "respostas" demonstra que o eram, também, os "remédios" aptos a serem mobilizados. Nesse sentido, talvez seja redutor, para esse universo, considerar que apenas as residências eram "mecanismos de controle" e, com elas, dimensionar em termos de eficácia somente "eventuais punições", como se estas fossem a única demanda e "resposta" possível diante das condutas antijurídicas do oficialato - embora, como visto, elas também ocorressem. Com efeito, havia, como demonstra particularmente o "serviço das partes", formas mais difusas, mas nem por isso menos importantes, de controle e disciplina. Afinal, o governo, a justiça e a graça régia, como há muito sinalizou Jon Arrieta Alberdi, também tinham por finalidade "[...] controlar, moderar, equilibrar, limitar, repartir, distribuir, es decir, de 'reprimir', en el sentido amplio del término [...]" as condutas e as formas de vida (ARRIETA ALBERDI, 1996, p. 217, 218).

Mas, acima de tudo, é preciso levar em conta que o "direito" de ter seus queixumes ouvidos e a mera possibilidade de apresentá-los era, per si, elemento de monta nessa cultura jurídica, desempenhando, além do mais, um papel basilar de vinculação entre os súditos e o monarca, bem como de integração funcional, em maior ou menor grau, de todo o oficialato instituído nos territórios para o "governo" (em sentido amplo) sob o princeps. ${ }^{96}$ Uma dinâmica que lança luz, enfim, sobre uma lógica de governo capilarizada,

\footnotetext{
${ }^{96}$ Como sintetizou Carlos Garriga, de integração de espaços políticos "jurisdicionalmente plurais e institucionalmente desarticulados" (GARRIGA, 2010).
} 
ainda que negociada, a partir da qual os súditos se faziam ouvir pelo poder régio e este se fazia presente no quotidiano do longínquo ultramar português - também - através de seu Conselho Ultramarino.

\section{Referências Bibliográficas}

ARRIETA ALBERDI, Jon. Justicia, gobierno y legalidad en la Corona de Aragón del siglo XVII. In: Estudis: Revista de historia moderna, no 22, 1996, pp. 217-248.

BARRAGÁN BARRAGÁN, José. Algunas consideraciones sobre los cuatro recursos de amparo regulados por las Siete Partidas. $2^{\mathrm{a}}$ ed. Guadalajara: Universidad de Guadalajara, 2000.

BICALHO, Maria Fernanda. "Possuidores despóticos": Historiografia, denúncia e fontes sobre a corrupção na América portuguesa. In: Revista Complutense de História de América, vol. 43, 2017. Disponível em: < $\underline{\text { https://revistas.ucm.es/in- }}$ dex.php/RCHA/article/view/56729>. Acesso em 1 mar. 2019. doi: https://doi. org/10.5209/RCHA.56729.

BICALHO, Maria Fernanda. Entre a teoria e a prática: dinâmicas político-administrativas em Portugal e na América Portuguesa (séculos XVII e XVIII). In: Revista de História, São Paulo, n. 167, julho/dezembro 2012, pp. 75-98. Disponível em: $<$ https://www.revistas.usp.br/revhistoria/article/view/49068 >. Acesso em 11 nov. 2018. doi: https://doi.org/10.11606/issn.2316-9141.v0i167p75-98.

BICALHO, Maria Fernanda; COSTA, André. O Conselho Ultramarino e a emergência do secretário de Estado na comunicação política entre o reino e as conquistas. In: FRAGOSO, João $\mathcal{E}$ MONTEIRO, Nuno (orgs.). Um reino e suas repúblicas no Atlântico: comunicações políticas entre Portugal, Brasil e Angola nos séculos XVII e XVIII. Rio de Janeiro: Civilização Brasileira, 2017.

BOSCHI, Caio. Projeto Resgate: História e arquivística (1982-2014). In: Revista Brasiselira de História, São Paulo, v. 38, n. 78, p. 187-208, Aug. 2018. Disponível em:

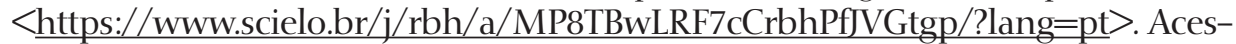
so em 12 nov. 2019. doi: http://dx.doi.org/10.1590/1806-93472018v38n78-09.

CAETANO, Marcello. O Conselho Ultramarino: esboço da sua história. Rio de Janeiro: Sá Cavalcante editores, 1969.

CAMARINHAS, Nuno. As residências dos cargos de justiça letrada. In: STUMPF E CHATURVEDULA (orgs.). Cargos e ofícios nas monarquias ibéricas. provimento, controlo e venalidade (séculos XVIIXVIII). Lisboa: CHAM, 2012.

CARDIM, Pedro. "Administração" e "governo": uma reflexão sobre o vocabulário do Antigo Regime. In: BICALHO, Maria Fernanda; FERLINI, Vera (orgs.). Modos de Governar: ideias e práticas políticas no Império Português, séculos XVI a XIX. $2^{\mathrm{a}}$ ed. São Paulo: Alameda, 2005.

CARDIM, Pedro. Cortes e Cultura Política no Portugal do Antigo Regime. Lisboa: Cosmos, 1998.

CARDIM, Pedro. O quadro constitucional. Os grandes paradigmas de organização política: a coroa e a representação do Reino. As cortes. In: MATTOSO, José (dir.); HESPANHA, António Manuel (coord.). História de Portugal. O Antigo Regime. v. 4. Lisboa: Estampa, 1998. 
CASTRO, Gabriel Pereira de. Tractatus de manu regia. Lisboa: Ex Typis Joannis Baptistae Lerz, 1742.

CERUTTI, Simona. Archaeology of rights: petitions and mercy in early modern societies. Columbia University, The Italian Academy, 2018.

CLAVERO, Bartolomé. Justicia y Gobierno. Economía y Gracia. In: Real Chancillería de Granada. V Centenario 1505-2005. Granada: Junta de Andalucía, 2006.

CRUZ, Miguel Dantas da. Um Império de conflitos: o Conselho Ultramarino e a defesa do Brasil. Lisboa: ICS: Imprensa de Ciências Sociais, 2015.

CURTO, Diogo Ramada. Cultura Imperial e Projetos Coloniais (séculos CV a XVIII). Campinas: Ed. Unicamp, 2009.

FERREIRA, Manuel Lopes. Pratica criminal expendida na forma da praxe observada neste nosso Reyno de Portugal [...]. Porto: Na Officina de Antonio Alves Rybeyro Guimaraens, 1767.

FRAGOSO, João E MONTEIRO, Nuno (orgs). Um reino e suas repúblicas no Atlântico: comunicações políticas entre Portugal, Brasil e Angola nos séculos XVII e XVIII. Rio de Janeiro: Civilização Brasileira, 2017.

GARRIGA, Carlos. Gobierno y Justicia: el gobierno de la justicia. Cuadernos de Derecho Judicial, $\mathrm{n}^{\circ}$ 7, 2008.

GARRIGA, Carlos. La ley del estilo 135: sobre la construcción de la mayoría de justicia en Castilla. In: Initium: Revista catalana d'historia del dret, 15, 2010, pp. 315-406.

GOUVÊA PINTO, António Joaquim de. Manual de appellações e aggravos, ou, deducção systematica dos principios mais solidos e necessarios, relativos a sua materia, fundamentada nas leis deste reino, para uso e utilidade da magistratura, e adovocacia. Segunda edição duplicadamente augmentada. Lisboa: Na Impressão Régia, 1820.

HANSEN, João Adolfo. A sátira e o engenho: Gregório de Matos e a Bahia do século XVII. São Paulo: Ateliê Editorial/UNICAMP, 2004.

HESPANHA, António Manuel. A política perdida: ordem e governo antes da modernidade. Curitiba: Juruá, 2010.

HESPANHA, António Manuel. Como os juristas viam o mundo. 1550-1750: Direitos, estados, coisas, contratos, ações e crimes. Lisboa: Antônio Manuel Hespanha, 2015.

HESPANHA, António Manuel. História das instituições: épocas medieval e moderna. Lisboa: Almedina, 1982.

HESPANHA, António Manuel. Justiça e litigiosidade: História e prospectiva. Lisboa: Calouste Gulbekian, 1993.

HESPANHA, António Manuel. Os poderes, os modelos e os instrumentos de controlo. In: MATTOSO, José (dir.) \& MONTEIRO, Nuno Gonçalo (coord.). História da vida privada em Portugal. Lisboa: Círculo de Leitores, 2011.

LOUREIRO, Marcello José Gomes. "Como poderemos restaurar depois de perdido, senão fazendo Justiça?" O Conselho Ultramarino e o diálogo com as conquistas em tempos de incerteza (1640-1656). In: Lócus: revista de história, v. 24, n. 1, p. 121-146, 2018. Disponível em: <https://periodicos.ufjf.br/index. $\mathrm{php/locus/article/view/20869/22386}>$. Acesso em 1 jan. 2021. doi: https://doi. org/10.34019/2594-8296.2018.v24.20869. 
MARTINS, Ana Canas Delgado. A documentação do Conselho Ultramarino como património arquivístico comum: subsídios à sua história. In: Revista Brasileira de História, v. 38, no 78, 2018. Disponível em: <https://www.scielo.br/j/rbh/a/ yVRbFLNyr5w4HrBmDy3dnVG/abstract/?lang=pt>. Acesso em 5 abr. 2019. doi: https://doi.org/10.1590/1806-93472018v38n78-02.

MASTERS, Adrian. A Thousand Invisible Architectis: Vassals, the petition and response system and the creation of Spanish Imperial. In: Hispanic American Historical Review, 98:3, 2018. pp. 377-406. Disponível em: <https://read. dukeupress.edu/hahr/article-abstract/98/3/377/135091/A-Thousand-Invisible-Architects-Vassals-the $>$. Acesso em 15 dez. 2018. doi: https://doi. org/10.1215/00182168-6933534.

MELLO, Isabele de Matos Pereira. Sindicantes e sindicados: os magistrados e suas residências na América portuguesa (século XVIII). In: Revista Historia y Justicia, 8, 2017. Disponível em: $<$ https://journals.openedition.org/rhj/930 $>$. Acesso em 20 dez. 2020. doi: https://doi.org/10.4000/rhj.930.

MONTEIRO, Nuno \& COSENTINO, Francisco. Grupos corporativos e comunicação política. In: FRAGOSO, João \& MONTEIRO, Nuno (orgs.). Um reino e suas repúblicas no Atlântico: comunicações políticas entre Portugal, Brasil e Angola nos séculos XVII e XVIII. Rio de Janeiro: Civilização Brasileira, 2017.

NUBOLA, Cecilia. La "via supplicationis" negli stati italiani della prima età moderna (secoli XV-XVIII). In: WÜRGLER, Andreas $\mathcal{E}$ NUBOLA, Cecilia. Suppliche e "gravamina". Politica, amministrazione, giustizia in Europa (secoli XIV-XVIII). Bologna: Il Mulino, 2002.

PEREIRA E SOUSA, Joaquim José Caetano. Primeiras linhas sobre o procésso criminal [...]. Lisboa: Typografia Rollandiana, 1820.

PEREIRA E SOUZA, Joaquim José Caetano. Classes dos crimes, por ordem systematica, com as penas correspondentes segundo a legislação actual. Lisboa: Regia Officina Typografica, 1803.

POLO MARTÍN, Regina Maria. Consejos y Consultas: La consulta como instrumento de gobierno en la Monarquía hispánica del Antiguo Régimen. Un estudio jurídico-institucional, con especial referencia al Consejo de Castilla. Bilbao: Fundación BBVA, 2018.

ROMEIRO, Adriana. Corrupção e poder no Brasil. Uma história, séculos XVII a XVIII. Belo Horizonte: Autêntica, 2017.

RUSSELL-WOOD, A. J. R. "Acts of Grace": Portuguese Monarchs and their subjects of African Descent in Eighteenth-Century Brazil. In: Journal of Latin American Studies, 32, 2000, p. 307-332. Disponível em: <https://www.jstor.org/stable/158567>. Acesso em 12 dez. 2019. doi: https://doi.org/10.1017/S0022216X00005757.

SANTANA, Ricardo George Souza. Lourenço de Brito Correa: o sujeito mais perverso e escandaloso. Conflitos e suspeitas de motim no segundo vice-reinado do Conde de Óbitos (Bahia, 1663-1667). Dissertação (Mestrado em História), Universidade Estadual de Feira de Santana, 2012.

SLEMIAN, Andréa E GARRIGA, Carlos. "Em trajes brasileiros": justiça e constituição na Américaibérica (c. 1750-1850). In:RevistadeHistória,USP,2013,n. 169, pp. 181-221.Dispo-

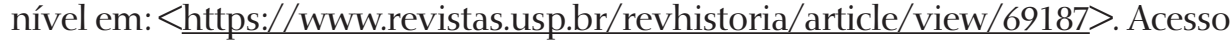
em 20 out. 2015. doi: https://doi.org/10.11606/issn.2316-9141.v0i169p181-221. 
SOUZA, Laura de Mello e. O sol e a sombra: política e administração na América Portuguesa do século XVIII. São Paulo: Companhia das Letras, 2007.

SOUZA, Laura de Mello; FURTADO, Júnia; BICALHO, Maria Fernanda. O governo dos povos. São Paulo: Alameda, 2009.

STUMPF, Roberta. Sobre as dúvidas que as autoridades na América portuguesa ofereciam ao centro da monarquia portuguesa. Uma reflexão sobre a prática e a comunicação política (c. 1600-c. 1750). In: Les Cahiers de Framespa, 30, 2019. Disponível em: $<$ https://journals.openedition.org/framespa/5647>. Acesso em 20 fev. 2020. doi: https://doi.org/10.4000/framespa.5647.

SUBTIL, José. Le Tribunal du Desembargo do Paço (Portugal, 1750-1833). IUS COMMUNE, Max-Planck-Institut, Vol. XIX, 1992, pp. 169-188.

SUBTIL, José. Os poderes do centro. In: MATTOSO, José (dir.); HESPANHA, António Manuel (coord.). História de Portugal. O Antigo Regime. v. 4. Lisboa: Estampa, 1998.

Recebido: 01/04/2021 - Aprovado: 23/09/2021

Editores Responsáveis

Miriam Dolhnikoff e Miguel Palmeira 